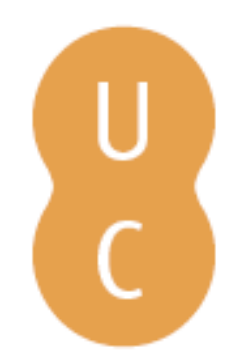

\title{
pommalina
}

\section{Martírio e identidade no advento da europa moderna: narrativa, memória colectiva e consciência europeia}

Autor(es): $\quad$ Urbano, Carlota Miranda

Publicado por: Imprensa da Universidade de Coimbra

URL

persistente: URI:http://hdl.handle.net/10316.2/38968

DOI: $\quad$ DOI:http://dx.doi.org/10.14195/978-989-26-0395-7_22

Accessed : $\quad$ 26-Apr-2023 10:16:10

A navegação consulta e descarregamento dos títulos inseridos nas Bibliotecas Digitais UC Digitalis, UC Pombalina e UC Impactum, pressupõem a aceitação plena e sem reservas dos Termos e Condições de Uso destas Bibliotecas Digitais, disponíveis em https://digitalis.uc.pt/pt-pt/termos.

Conforme exposto nos referidos Termos e Condições de Uso, o descarregamento de títulos de acesso restrito requer uma licença válida de autorização devendo o utilizador aceder ao(s) documento(s) a partir de um endereço de IP da instituição detentora da supramencionada licença.

Ao utilizador é apenas permitido o descarregamento para uso pessoal, pelo que o emprego do(s) título(s) descarregado(s) para outro fim, designadamente comercial, carece de autorização do respetivo autor ou editor da obra.

Na medida em que todas as obras da UC Digitalis se encontram protegidas pelo Código do Direito de Autor e Direitos Conexos e demais legislação aplicável, toda a cópia, parcial ou total, deste documento, nos casos em que é legalmente admitida, deverá conter ou fazer-se acompanhar por este aviso.

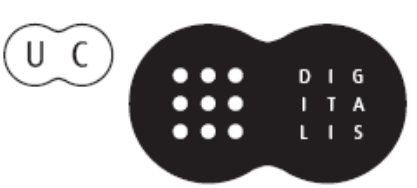


Nair de Nazaré Castro Soares

Santiago López Moreda

Coordenação

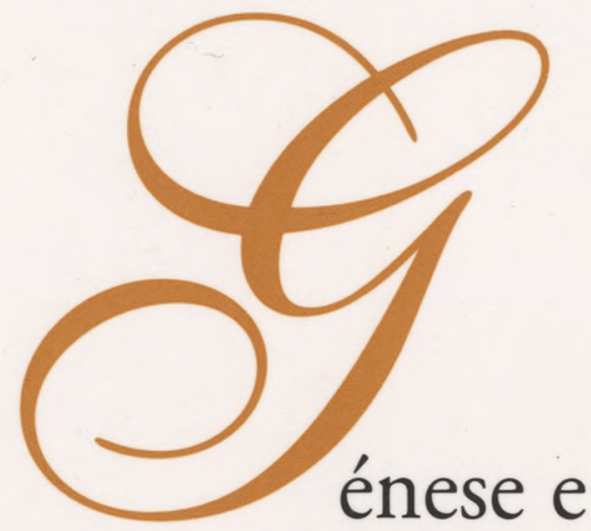

Consolidação da Ideia de Europa

Vol. IV

Idade Média e Renascimento

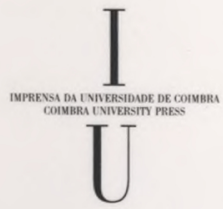

- COIMBra 2009 


\title{
MARTÍRIO E IDENTIDADE NO ADVENTO DA EUROPA MODERNA. NARRATIVA, MEMÓRIA COLECTIVA E CONSCIÊNCIA EUROPEIA.
}

\author{
CARlota Miranda Urbano \\ (Universidade de Coimbra)
}

$\mathrm{O}$ advento da modernidade na cultura europeia, etiquetado tantas vezes como o advento do espírito crítico e como afirmação do antropocentrismo, constitui um período de cruzamento de difíceis tensões no mundo ocidental, conflitos sangrentos, geradores de vítimas que são identificadas pelas suas comunidades como mártires. Estes conflitos surgem, grande parte das vezes, marcados por requintes de violência que deixam no retrato dos pioneiros da modernidade, de que hoje somos herdeiros, uma marca de ambivalência difícil de integrar. Tanto mais que, na origem dos principais conflitos que geraram inúmeras vítimas e mártires estão, não só uma concepção do homem e do mundo, como também uma forma de estar e de viver essencialmente religiosa. $\mathrm{O}$ advento da modernidade, com efeito, é uma fase da história tão ou mais religiosa que a dos séculos ditos medievais. O que nela há de novo é uma outra interpretação do religioso, ou uma nova leitura das fontes e o início de uma globalização que ofereceria a via, quer da realização da vocação universal do cristianismo missionário, quer do desenvolvimento de um comparativismo religioso capaz de propor a desmistificação do cristianismo, reduzido a mais um mito.

Marcado pelo indiferentismo e pelo relativismo religioso que herdou da modernidade, o nosso tempo tem dificuldade de aceitar que o momento histórico dessa primeira globalização à escala planetária seja tão marcado por um sentido tão forte do homo religiosus como o que podemos constatar nas fontes que nos transmitem esses conflitos sangrentos, quer elas sejam transmitidas na perspectiva da vítima quer na do perseguidor. A representação ocidental moderna do indivíduo na sua plena liberdade de auto-determinação julga(va)se incompatível com o fenómeno religioso, por isso o omite facilmente.

Acresce ainda que o nosso tempo é useiro em juízos de valor sobre o passado e os seus actores, rápido a julgar e condenar os seus ante(passados). Trata- 
-se, na interessante observação de René Girard, de uma outra característica da mundividência do homem moderno do mundo ocidental: a capacidade de continuamente se auto-criticar. Como escreve este filósofo dos nossos dias, nós, ocidentais, somos sempre nós mesmos e o nosso próprio inimigo, condenamos com veemência o que somos ou o que julgamos ser. No fundo temos uma paixão pela 'auto-crítica', que não existe senão nos povos tocados pela civilização judaico-cristã (Girard, 2001:9).

A Europa moderna, desde o seu advento, foi palco de mecanismos internos de perseguição, de guerras religiosas, de ideologias totalitárias e, no contexto da civilização ocidental à escala planetária, foi objecto de mecanismos externos de perseguição étnica e religiosa. Inúmeras vítimas são apontadas como mártires da fé por recusarem renunciar ao seu credo. O tempo das reformas e da difusão universal do cristianismo ocidental tem sido visto e observado como o tempo do regresso do mártir, nas palavras de Lestringant, o tempo do escândalo ou do paradoxo, do 'eterno retorno' do mártir que, contra todas as previsões, permanece na actualidade de uma das épocas mais brilhantes da civilização ocidental (Lestringant, 2004: 9).

Por que razão houve lugar para novos mártires neste tempo? Como os entenderam os seus contemporâneos? Que efeito tiveram esses martírios na construção de uma identidade europeia e ocidental modernas? Na perspectiva de quem como nós se dedica ao estudo dos textos desta fase tão conturbada da história da Europa, ao estudo das suas fontes literárias escritas na língua culta e internacional da época, o Latim, não podemos deixar de observar a estranha fortuna do tema do martírio, a renovada projecção heróica dos antigos e dos novos mártires, retomando os modelos literários do paradigma greco-romano numa síntese de motivos clássicos e bíblicos. Sem a pretensão de alcançar respostas que esgotem o alcance da questão, tentamos compreender um pouco mais o significado deste fenómeno de perseguição e martírio na aurora da modernidade, e procuramos fazê-lo a partir da 'escola da Literatura', para usar a expressão de Girard (Girard, 2001: 159).

\section{MARTÍRIO, REPRESENTAÇ̃̃O E IDENTIDADE}

Esta aproximação da figura do mártir a partir das suas representações literárias, longe de se pretender exclusiva, é, em nosso entender, fundamental para a sua compreensão. Por si só, ela não explicará as razões da sublimação da morte e do sofrimento em nome de um credo, de uma fé, de uma religião, isto é, ela não explicará as origens do martírio, mas terá algo a dizer sobretudo em 
relação ao acolhimento da figura do mártir e à sua projecção como paradigma humano.

Com efeito, como observa pertinentemente Marie-Françoise Baslez, ${ }^{1}$ a identificação do mártir releva sempre de uma definição subjectiva. O perseguido não é necessariamente um mártir e, para os perseguidores, acrescentariamos, não é de todo um mártir. É a representação que uma comunidade faz da morte de um dos seus membros, ou a representação que ele próprio faz da sua morte que o identificam como mártir. Essa representação tem lugar na narrativa, seja ela literária seja iconográfica, e é por intermédio dessa narrativa que $o$ mártir passa a integrar a memória da comunidade como paradigma, através de um processo de reconhecimento colectivo que se traduz a maior parte das vezes na transmissão de uma tradição e na instituição de um culto. Por isso faz todo o sentido a afirmação de Baslez: "l'étude du martyre relève de l'histoire des représentations" (Baslez, 2007:10).

Se tivermos em conta o martírio na Antiguidade não duvidamos da sua função identitária do ponto de vista eclesial, quer da Igreja universal, quer das Igrejas locais. Para os cristãos, os mártires são as pedras fundadoras das suas comunidades, das suas cidades, são os seus protectores. A posse das suas relíquias é garante dessa tutela. Desde as suas origens, o cristianismo associa perseguição e martírio à difusão da sua fé, ideia que circula na literatura martirológica cristã na expressão frequentemente repetida: "sangue de mártires, semente de cristãos" (glosando Tertuliano no Apologético, 50 : "quoties mettimur a vobis, plures efficimur. Semen est sanguis christianorum."

O sucesso da fórmula comprova o lugar fundador da figura do mártir e do seu valor para a comunidade. Em certa medida podemos ver nele a herança da figura do herói celebrado pelo poeta antigo diante da cidade. Não é ele também alimento de identidade através da renovação cíclica de determinados rituais de cidadania, agora cidadania cristã? A leitura ritual da literatura edificante e celebrativa dos mártires, quer em contexto litúrgico quer fora dele, tem seguramente um papel activo na construção da 'cidade' eclesial. Assim sendo, compreendemos que, em certa medida e salvaguardando diferenças essenciais, os mártires dão continuidade aos heróis e devem-lhes, em grande parte, a sua formulação literária, herdeira da cultura greco-romana.

Seguramente, a narrativa martirológica, quer pela leitura dos Acta e das Passiones, quer pela leitura e recitação de Hinos como os de Prudêncio, quer ainda pelas homilias dos dias litúrgicos dedicados aos mártires, contribuiu para

${ }^{1}$ Baslez, Marie-Framçoise, Les persécutions dans l'antiquité. Victimes, héros, martyres, Fayard, 2007. 
cristalizar o paradigma heróico do mártir que sobreviveria ao longo da Idade Média, atravessando a modernidade até aos nossos dias, mesmo noutras tipologias da santidade canonicamente reconhecida. A representação deste paradigma de realização plena do humano no divino, congregou a nova ordem do cristianismo nascente, e com o seu poder identificador respondeu à necessidade de a igreja incipiente se afirmar perante uma maioria que lhe era adversa e, mais tarde, perante o mundo muçulmano. Sobretudo quando se celebrava um mártir da cidade ou da diocese, ou se esta tinha em seu poder as suas relíquias, este paradigma constituía um bem indiscutivelmente precioso para as comunidades no aprofundamento das suas raízes espirituais, sociais e mesmo políticas. Os mártires da cidade eram os seus protectores, a sua tutela, os seus lares, eram para elas uma autêntica fonte de soberania.

A representação literária do martírio na antiguidade tinha, assim, mais que a do herói, uma função celebrativa da comunidade, isto é, da ordem de valores com que esta se identificava. E, para que esta comunidade identificada se pudesse reproduzir socialmente nas sucessivas gerações, era fundamental a proposta do seu paradigma humano, o mártir.

Assim se compreende que St. ${ }^{\circ}$ Agostinho, no De Ciuitate Dei (X, 21) lamentasse o facto de os mártires cristãos não terem sido designados 'heróis' à maneira grega, pois, em seu entender, mereciam-no. Provavelmente compreendera já então o papel fundamental do mártir cristão definido, como novo paradigma humano. Daí o profundo alcance da sua observação. Na verdade, sobretudo em ambiente grego, o termo heros tinha ainda forte conotação religiosa e revelava o respeito sagrado que despertavam grandes figuras humanas que depois da morte adquiriam um estatuto particular próximo dos deuses. Por isso era evitado pelos autores cristãos. Os autores latinos, porém, porque o termo heros fora já relativamente laicizado, sentiam-se mais à vontade para usar o vocábulo, depurado de conotações estritamente religiosas e, portanto, pagãs, aplicado aos mártires. Como observa Fredouille, Cícero empregava já o termo 'heros' com o sentido literário de 'personagem' e, por outro lado, em Roma, o culto dos heróis não alcançara a dimensão que teve no mundo grego (Fredouille, 1997: 15).

Desde os primeiros tempos do cristianismo, pois, a figura do mártir foi-se apresentando como um novo paradigma humano de heros que se afirmava no 'espaço de um novo agonismo' (Miranda, 2002: 184).

A força identitária do martírio reside em parte também no facto de, na antiguidade, ele surgir muitas vezes como consequência da recusa de identificação com a norma da comunidade perseguidora. Forçados a sacrificar aos deuses, os cristãos que não o fizessem eram assim submetidos a um verdadeiro 
teste identitário, na medida em que esse gesto ritual assinalava a diferença entre a cidadania oficial e o cristianismo. O que constituía para o mártir um processo de identificação pela negativa oferecia à sua comunidade pela sua publicitação uma ocasião de identificação pela positiva. Na expressão de Alison Ellliot, o ethos do mártir é simultaneamente dissociativo e integrador (Elliot, 1987: 19). Ele integra-se na sua comunidade dissociando-se do seu passado pagão ou do poder perseguidor do 'mundo velho' para o qual ele morre, integrando-se no 'mundo novo' post reuelationem.

Proposto como paradigma, o mártir, com o brilho paradoxal da sua derrota aos olhos do mundo representada como vitória aos seus próprios olhos e aos da sua comunidade, conferia especial eficácia à mensagem missionária.

Os Acta martyrum, assim, são como que a ilustração humana e divina, a verificação 'experimental' daquilo que o Evangelho de S. Mateus intuíra associando intimamente perseguição e missão.

\section{MÁRTIR, FONTE DE IDENTIFICAÇÃO COMO VITIMA EXPIATÓRIA?}

A questão surge como um desafio lançado pela original e polémica tese de René Girard: poderá o mártir constituir uma vítima expiatória no sentido pleno? Num estudo anterior (Miranda Urbano, 2004: 54-55) já tivemos oportunidade de observar em relação ao fenómeno do martírio dos cristãos no mundo nipónico, quando estava em génese a unificação do Japão, que, do ponto de vista da comunidade perseguidora, se observa na perfeição o mecanismo do bode expiatório. Aplicando a esta realidade a tese girardiana ${ }_{2} \mathrm{o}$ objecto estranho (o cristão) odiado terá funcionado como elemento agregador e unificador dos 'rivais'. Contudo, poderemos considerar que esse mecanismo expiatório pôs em evidência o efeito catártico da violência colectiva? Isto é, o mecanismo persecutório gerador da vítima cumpriu cabalmente o seu desígnio de a apresentar como culpada e de unificar nessa ilusão os rivais? Com efeito, essa perseguição não tinha origem na unanimidade da comunidade perseguidora, antes apenas na sua maioria guiada pelas elites, por isso entendemos que não chega a verificar-se a reconciliação dos rivais contra a vítima, por isso ela não é divinizada, não chegando a cumprir-se a ilusão mítica.

Se tivermos em conta as perseguições modernas que o mundo cristão moveu contra a feitiçaria, ou contra os judeus, que confissões religiosas moveram umas contra as outras, que ideologias recentes moveram contra o judaísmo, contra a igreja católica, contra as religiões em geral, etc...também não logramos identificar um processo completo de funcionamento do meca- 
nismo de bode expiatório. A ilusão mimética que, segundo Girard, nas sociedades míticas garante a unificação da comunidade contra a vítima, fundando a harmonia social na 'mentira das unanimidades violentas' (Girard, 2001: 71), no mundo moderno já não tem lugar. As comunidades de matriz judaica e cristã não resistem mais que as outras ao contágio da violência mimética mas haverá nelas sempre pequenas minorias, restes trop infimes, na expressão de Girard, oferecendo resistência e impedindo que se encerre o ciclo sobre a culpabilização da vítima. Com efeito, para Girard, como observa Miguel Costa, 'o mundo moderno já não consegue produzir verdadeiros mitos' (Costa, 2000: 120). Acrescentaria Girard, julgamos, graças a essa revelação da inocência da vítima que o ocidente moderno herdou da tradição judaico-cristã.

Mas, se do ponto de vista da comunidade perseguidora, a vítima já não é fonte de coesão e de identidade, julgamos que, na perspectiva da comunidade perseguida, a que Girard não fez qualquer referência (tanto quanto julgamos saber), a vítima funciona como elemento de unificação na construção de uma identidade comunitária. Atrevemo-nos mesmo a sugerir que a vítima, no contexto judaico-cristão, denunciador da sua inocência e da culpabilização da comunidade persecutória, tem um carácter fundacional para a comunidade perseguida. Intrinsecamente inocente, esta vítima não é sacralizada (como o era no mecanismo arcaico do bode expiatório), permanece humana, ainda que lugar de encontro entre o humano e o divino, e gera um efeito de identificação na comunidade. Um argumento que poderíamos apontar para a defesa desta hipótese é que, como observa Brad Gregory, que nos apresenta um estudo comparativo dos martirológios católico e protestantes, a existência de martírios foi um factor determinante na definição e radicalização dos confessionalismos em que a cristandade se viu dividida. Cada morte de um mártir diminuía as possibilidades de reconciliação com os grupos rivais, reforçando a coesão interna de cada confissão (Gregory, 1999: 345).

\section{PERSEGUIÇÃO E MARTÍRIO NA EUROPA DAS REFORMAS}

Tal como nos primeiros séculos do cristianismo, o martírio e a perseguição são vistos pelos cristãos desta época à luz de uma espécie de protomartírio, o do "mártir" por excelência, Jesus, que veio "para dar testemunho da Verdade" (hína martyrêsô tê' alêtheía - Jo 18,37), nas suas próprias palavras a Pilatos. Esta atenção ao Cristo sofredor constitui um lastro comum às duas Europas, a das Reformas, herdeira mais directa do movimento espiritual do fim da Idade Média, a devotio moderna, que se identifica sobretudo com Cristo 
como servo sofredor, mas também a da Reforma Católica, quer na sua efervescência mística e espiritual, quer, sobretudo, na sua incomparável liberdade no âmbito da expressão plástica.

Como observa Brad Gregory (1999: 61), a intensa corporeidade de Cristo patente na representação do crucifixo traduz a devoção tardo-medieval pela paradoxal fragilidade do corpo de Deus-salvador. A sua morte e paixão, o "martírio"sacrifício redentor do homem, são o protótipo fundamental do fiel, o modelo a imitar na capacidade de exercitar a virtude da Patientia, ou resistência ao sofrimento. A larga representação da morte e crucifixão do salvador, por vezes considerada um dos traços de uma obsessão medieval pela morte, é afinal uma outra face da devoção pela dimensão humana de Jesus, como a chamada devoção do nome de Jesus - também nascida no final da Idade Média - de S. Bernardino de Sena (1380-1444). Cabe aqui pertinentemente notar que a própria emergência do antes raríssimo antropónimo 'Jesus' na teologia e na devoção particular, reflecte uma deslocação do acento sobre a divindade do Verbo Incarnado, própria, grosso modo, do I milénio cristão - que preferia o título messiânico por excelência de 'O Cristo' - em favor da consideração, gradual mas constante, ao longo do II milénio, da sua humanidade. ${ }^{2}$ Caso paradigmático desse dinamismo é também o do respectivo anagrama grego IHS, difundido maciçamente pela Ordem de Santo Inácio de Loyola, (para a qual quis precisamente o "nome de Jesus"), mas recuperado já nos alvores da modernidade (usara-o S. Bernardino de Sena), a partir da devoção de Santo Inácio de Antioquia. De facto, a recuperação do Nome de Jesus e a sua conexão à contemplação da Paixão e respectivas devoções espirituais (pensemos nos Hinos luteranos ou no género musical das Paixões e das Cantatas, em âmbito protestante, ou em devoções como a das Cinco Chagas e do Bom Jesus, tão importantes no contexto lusófono, ou do Coração de Jesus, unificador de todo orbe católico) são fenómenos a ler no contexto do geral movimento europeu do retorno às fontes. Não é de somenos importância recordá-lo aqui, pois será através de consequências capilares como estas que as ‘duas Europas' mostrarão a sua unidade cultural de fundo.

Embora depois da cristianização do império romano as possibilidades de concretizar o heroísmo supremo dos cristãos, o martírio, fossem grandemente reduzidas, os mártires e a narrativa dos martírios continuaram a merecer especial destaque no culto dos santos ao longo da Idade Média. Eles eram, a um tempo, especialmente favorecidos por Deus na capacidade de resistir aos tormentos e, para os fiéis, intercessores especialmente poderosos diante de Deus.

${ }^{2}$ A síntese far-se-á discretamente através da geral supressão paulatina do artigo ou até da justaposição pura e simples - cfr. o italiano Gesucristo - entre os dois vocábulos. 
Uma piedade valorizadora da imitação da figura de Cristo, da sua morte e paixão, da sua capacidade de resistência no sofrimento, a quem as circunstâncias históricas e religiosas dos séculos das reformas proporcionaram perspectivas reais de martírio, transformaria facilmente o desejo de o imitar no desejo explícito de o imitar morrendo. As guerras religiosas que dilaceraram a Europa e as perseguições que as várias confissões cristãs moveram entre si foram ocasião de muitas mortes pela fé. Como observa Gregory, o facto de os vários grupos religiosos partilharem numerosas convicções religiosas e, por conseguinte, o facto de os grupos rivais enfrentarem, não um estranho completamente 'outro', mas, um europeu contemporâneo, por assim dizer, um 'irmão', tornava muito mais profundos os efeitos das divisões doutrinais. Digamos que a forte identificação das confissões religiosas com a natureza fundamental de uma verdade de fé revelada no cristianismo, tornava inconciliáveis as diferentes doutrinas. Não era simplesmente uma identidade cultural que estava em jogo, mas, para estes homens, era a própria salvação do homem que estava em jogo. Como observa Gregory (1999: 347), como poderíamos esperar deste tempo pré-relativismo, que antepusesse a prioridade de uma convivência pacífica à verdade sobre Deus? Era o mesmo que imaginar que Lutero, Calvino, Zwinglio, Fisher, Thomas Moro, Loyola, e tantos outros, fossem, não como foram realmente, mas como 'hoje' esperaríamos que fossem. Que lugar haveria para a actual 'tolerância' religiosa num mundo em que os cristãos se dispunham a morrer pelas suas doutrinas? Havia realmente, na Europa de então, luteranos, anabaptistas, católicos, verdadeiros candidatos ao martírio em circunstâncias de perseguição.

Como acima dissemos, estas mortes, mas também as suas celebrações como martírios, reforçariam a identidade de cada grupo confessional, tornando progressivamente mais longinqua a possibilidade de uma reconciliação nas décadas seguintes. Amplamente divulgadas em vários martirológios, relatos e representações iconográficas, elas consolidam os laços identitários quer das comunidades reformistas emergentes, quer as dos cristãos ligados a Roma. A par da controvérsia doutrinal, mediam forças também os panfletos com cartas de mártires no cárcere, os relatos dos martírios, os elogios e os hinos em louvor destes novos heróis com que cada confissão se identificava. Tratava-se, na expressão de Lestringant, de uma verdadeira 'política do martírio', uma guerra de mártires e de martirológios (Lestringant, 2004: 116), na qual as igrejas reformistas levavam algumas décadas de avanço, pois começaram primeiro a divulgar as suas relações de martírios. Antes do grande martirológio evangélico de John Foxe, Acts and Monuments (1563) já circulavam, desde cerca de 1530 , centenas de panfletos sobre os mártires protestantes. O primeiro 
panfleto, editado em 1523 para divulgar a execução dos frades agostinhos desse mesmo ano, teve dezasseis edições, realizadas em sete cidades alemãs. $\mathrm{O}$ Livre des Martyres de Jean Crespin já conhecera várias edições em francês e em Latim (desde a primeira em 1554), e conheceria mais tarde a tradução alemã em 1590. Dos Anabaptistas, sobretudo os pacifistas, ciclicamente massacrados pelos filões reformistas vencedores, para além da colecção martrirológica que conheceu onze edições entre 1562 e 1563, importa considerar as cartas dos mártires, as poesias e hinos, as narrativas musicais e canções que circulavam em panfletos pelo menos desde 1520 (Gregory 1995:4).

A Europa Católica, algumas décadas mais tarde, também publicaria as suas recolhas de martírios. O católico inglês Richard Verstegan publicou em 1583 em Latim e depois em Francês as Descriptiones quaedam illius inhumanae et multiplicis persecutionis, quam in Anglia propter fidem sustinent Catholici Christiani. Segundo Gregory, a esta mesma matéria, os mártires católicos de Inglaterra, são dedicadas, em parte ou no todo, cerca de 50 publicações diferentes entre 1566 e 1640, obras publicadas não só em Inglês mas também em Latim, Francês, Espanhol, Italiano e Alemão (Gregory 1995: 4)

Depois da Briefve Description, versão francesa daquela obra de Verstegan, o mesmo autor lançava-se num empreendimento mais vasto, o célebre Theatrum crudelitatis haereticae, que conheceu várias edições em latim, $(1587,1588,1592$ e 1604$)$ e em francês $(1587,1588$, e 1607). É um dos mais conhecidos martirológios desta época e um dos raros que integra mártires de vários pontos da Europa nos seus 29 elogios de vítimas das perseguições religiosas em Inglaterra, França e Países Baixos (Gregory 1995: 290). Esta obra foi objecto de edição crítica e anotada por Frank Lestringant em 1995 (Paris, Éditions Chandeigne). No contexto de uma Europa em que a Espanha Católica se afirma vencedora nas várias frentes, esta obra, desenhando um verdadeiro 'teatro de imagens' (como o título anuncia) e um cenário apocalíptico que reúne a França, os Países Baixos e a Inglaterra, assume uma dimensão europeia.

Embora a 'parte católica' tivesse entrado mais tarde no afã editorial, rapidamente recuperou a diferença de décadas e, sobretudo em termos 'concorrenciais', ganhou em impacto e dimensão internacional. Para tal, julgamos que contribuíram dois factores. Por um lado, os editores de martirológios protestantes, quando passamos ao período das guerras de Religião, são confrontados com falta de matéria. De testemunhos individuais e autênticos de defensores da causa, que na hora do suplício proclamam a sua fé, passam a dispor de uma multidão anónima que sucumbe nos conflitos armados, com mortes de um lado 
e de outro. Os católicos, porém, em breve começam a dispor de numerosos mártires das missões. Por outro lado - e este factor terá também pesado bastante - os martirológios católicos venciam em impacto propriamente religioso e não menos em eficácia retórica. Sem esquecer o alcance radicalmente diferente que lhes emprestava a possibilidade de um contexto especificamente cultual, embora morigerado pelos novos procedimentos canónicos de beatificação e canonização, a narrativa católica aparece ainda enriquecida pela profusão da imagem que, muito mais que simples ilustração, era um veículo de emoções e de sentido, dotando o texto da possibilidade de descer da abstracção ao concreto e, seguramente, de potenciar a sua eficácia ad deuotionem promouendam. Estes martirológios, muitas vezes verdadeiros livros de imagens onde a contemplação apoia a leitura, mesmo quando não dispunham de tantas gravuras, tinham no texto a marca da visibilidade. Este era, no seguimento da tradição da literatura martirológica antiga, suficientemente descritivo para conseguir representar e tornar visíveis as realidades a que se reportava. Já os reformistas, com maior ou menor grau de iconoclastia recusavam a imagem sempre associada ao risco de idolatria. Os seus martirológios têm, quando muito, uma ilustração no frontispício e, se representam alguns mártires no tormento, é para concluírem do inquestionável triunfo da Palavra. ${ }^{3}$ Crespin, conforme o cita Lestringant (Lestringant, 2004: 119), na sua Histoire des Martyres, adverte o leitor do risco de idolatria e afirma que a sua obra não é um 'relicário destinado a suscitar devoção nos fiéis', mas uma 'palavra viva'.

As gravuras do Theatrum Crudelitatis...(para evocar o exemplo mais significativo) impressas em Antuérpia e espalhadas por toda a Europa, tinham eco nos frescos das igrejas, nos retábulos e nas telas e, graças à imprensa, ultrapassavam fronteiras, contribuindo para consolidar e perpetuar a construção de uma memória colectiva na continuidade de uma tradição que prezava a imagem, por um lado, e por outro não podia dissociar-se da teatralidade que herdara da condição espectacular dos primeiros martírios cristãos ocorridos no contexto do circo. Quanto aos protestantes, sem recusar completamente esta teatralidade, insistem sobretudo na palavra viva do martyrion, o "testemunho". No fundo, tanto uns como os outros, através da divulgação editorial de relatos de martírios e de testemunhos de mártires (perdoe-se o pleonasmo), pretendem fazer do seu leitor uma outra testemunha, mais que um espectador. No plano ideal, a eficácia pretendida é a de que o leitor/espectador, tocado pelo testemunho do mártir, (e passe mais uma vez o pleonasmo) se torne também ele uma testemunha, que por sua vez desencadeará nos outros o mesmo efeito.

\footnotetext{
${ }^{3}$ Por exemplo, fazendo sair da sua boca uma legenda com versículos dos Evangelhos.
} 
Em última análise, os martirológios, proporcionando o testemunho à comunidade que reconhece na vítima o mártir, como que se constituem prova documental do martírio. Eles divulgam e autentificam o gesto do mártir. Isto, porém, não corresponde a uma novidade no martírio moderno pois já os primeiros cristãos não se poupavam a riscos para conseguir as Actas dos processos de martírio ou, pelo menos, relatos com base em testemunhos oculares. Por essa razão, alguns magistrados interditavam o registo escrito dos interrogatórios ou mandavam queimar os processos. Outras vezes, estes eram roubados e destruídos. ${ }^{4}$ Já no séc. XVI, o calvinista Agrippa Aubigné relata na Confession catholique du Sieur de Sancy que, muitas vezes, os processos judiciais das vítimas da perseguição eram roubados dos cartórios (por zelosos fiéis reformados), ou, outras vezes, atados ao pescoço do condenado para com ele arderem.

O martírio e o martirológio contribuíam, assim, para reforçar ou fundar a identidade das várias confissões religiosas. No caso das novas confissões, o derramamento de sangue como que conferia autoridade às novas doutrinas. No caso dos católicos, o apelo à identificação com os primeiros mártires cristãos e uma interpretação sacrificial do martírio ${ }^{5}$ (incompatível com as doutrinas protestantes), reforçavam a sua identificação com o tempo fundador do cristianismo, numa espécie de reactualização ou refundação.

$\mathrm{Se}$, de acordo com a doutrina católica reforçada no Concílio tridentino, os santos tinham realmente um papel intercessor, questionado por Lutero, e se o sofrimento dos mártires completava misticamente o sacrifício de Cristo, o próprio entendimento do mártir, entre católicos e protestantes era necessariamente diferente. Independentemente das divergentes leituras do martírio, porém, ele tinha em todo o caso um efeito identitário. Sobretudo no mundo católico, a sua celebração, não só na literatura como nas artes plásticas, mas também na devoção privada e no culto litúrgico (este inaceitável nas confissões protestantes, uma vez que era considerado idolatria) contribuíram para uma verdadeira mística de desejo do martírio e para uma pedagogia valorizadora do martírio enquanto suprema participação da paixão de Cristo, sinal evidente do Corpo Místico de que fala S. Paulo (Col., 1, 24). Apresentar o modelo martirial com exempla contemporâneos que resultavam, quer dos confrontos religiosos na Europa, quer das missões na Igreja em expansão, promovia nas novas gerações o desejo de imitar os feitos destes novos heróis, potenciando os efeitos identitários do mártir. Com efeito, identificação e desejo estão também intimamente

\footnotetext{
${ }^{4}$ Veja-se por exemplo a informação de Prudêncio no Peristephanon I, v. 75-78.

${ }^{5}$ Sobre a consciência da dimensão sacrificial do martírio no séc. XVII vd. Miranda Urbano, Santos e Heróis ...pp 213-223.
} 
relacionados, e podem ser objecto de uma pedagogia. Identifico-me desejando, aprendo a desejar, contemplando e experimentando (Lopes, 2003).

A Companhia de Jesus, nascida precisamente no contexto das reformas e das cisões doutrinais que dividiram o cristianismo ocidental, apurou essa pedagogia do paradigma pela narrativa e pela celebração da memória, explorando dimensões como a imaginação e a afectividade. Em duas 'frentes de combate', na Europa a defesa da ortodoxia, e no Novo Mundo e no Oriente a missionação, a Companhia de Jesus dispunha na sua acção pedagógica de numerosos exempla paradigmáticos de heróis da patientia christiana. Consciente do capital que esses exempla constituíam, também a Companhia fez sua divulgação por meio das Cartas Ânuas, de Relações, Elogios, Colecções de Vidas, Poemas celebrativos etc... Estas obras, para além de prestigiar a jovem Ordem Religiosa (que assim patenteava os frutos da sua acção apostólica), cumpriam os objectivos informativos, celebrativos e pedagógicos e, juntamente com as memórias litúrgicas, contribuiam para o fazer memória, prática simultaneamente intelectual e afectiva dos Exercícios Espirituais de S. Inácio (Loyola, Exercicios Espirituais $\$ 118$ a 125).

Os noviços e os alunos dos numerosos Colégios da Companhia, na Europa e nas missões dos reinos europeus, são feitos testemunhas dos martírios que, de longe, se faziam perto, através da leitura das Cartas, da celebração das suas memórias litúrgicas e através até dos exercícios literários narrativos e dramáticos. Muitas destas testemunhas deixariam a Europa e experimentariam elas próprias o martírio. Seguindo a lógica paradoxal do martírio, os reveses e os recuos na missionação, a perda de missionários às mãos de ataques calvinistas ou de naufrágios, na sua divulgação literária, invertem-se, conferindo à derrota a dimensão de aparência e apresentando com toda a evidência o triunfo das vítimas. Não raro, a representação iconográfica do martírio apresenta já a própria apoteose dos mártires, a sua entrada na glória divina. Quando tal se verifica, Deus Pai ou o próprio Cristo, encimando a representação entre as nuvens, acolhem os heróis a quem os anjos entregam as palmas ou as coroas, símbolos agónicos da antiguidade, sublimados e perpetuados na expressão do triunfo eterno.

\section{A EUROPA MODERNA EM IDENTIFICAÇÃO COM UMA VOCAÇÃO UNIVERSALIZANTE}

Os martírios que tiveram lugar nas longínquas paragens do Oriente, largamente divulgados quer sob a forma dos relatos das Cartas, quer sob a forma celebrativa dos elogios, das representações iconográficas e das composições poéticas, ressoavam fortemente na Europa. 
Conscientes da importância da sua missão, as ordens missionárias, especialmente a Companhia de Jesus, sentiam o imperativo de dar a conhecer a sua própria história na Europa, e no resto do mundo. Este imperativo enquadrava-se na mais genuína mentalidade humanista que via a história como uma 'escola de virtudes' destinada a uma função retórica e pedagógica inalienável (Soares, 1992: 160).

Num discurso celebrativo do triunfo, mas que não omitia as perdas de recursos humanos e os atrasos na missionação que resultavam da clandestinidade dos missionários e da sua morte, aquela divulgação despertava na Europa uma nostalgia dos tempos fundadores do cristianismo. A notícia de muitos martírios entre os cristãos autóctones reforçava esta tendência para reviver os tempos paradigmáticos do primitivo cristianismo, um pouco à semelhança do que experimentavam as igrejas reformadas e do ideal que movera os irmãos da Vida Comum, antepassados do movimento da devotio Moderna. Os missionários que viviam na clandestinidade identificavam-se com os primeiros cristãos perseguidos e as suas cartas na Europa atraíam novas vocações para arrancar do domínio do Demónio os povos que ainda não conheciam a revelação de Cristo. Tudo se resumia neste combate contra o Pai da Mentira que mantinha cativos os ignorantes da fé cristã, por meio das falsas aparências dos deuses locais. Para os missionários, pelo baptismo, o outro passava a ser, antes de mais, o fiel que nascia para uma nova realidade. $\mathrm{O}$ cristianismo convivia então muito de perto com a sua missão universalizante e os missionários queriam chegar a todos e a cada um.

Religião incarnada, não no vazio, mas sempre num determinado povo, e simultaneamente religião universal, o cristianismo da Europa Moderna não era uma religião para a Europa. Esta consciência da missão universalizante, enraizada no âmago da revelação cristã e reforçada pelas relações do cristianismo nascente com o estoicismo, foi, no início da modernidade, indissociável do nascimento de uma consciência europeia do universal.

A noção evangélica de que 'não há judeu nem grego; não há servo nem livre, não há homem nem mulher, pois todos vós sois um só em Cristo' (Gal. 3, 28), converge na ideia estóica de uma espécie de fraternidade universal que abrange o grego e o bárbaro. Lembremos que, embora a recepção do estoicismo no humanismo cristão do séc. XVI se dividisse entre a recusa e a convergência, quer entre católicos quer entre protestantes, foi feita a sua reabilitação como filosofia do mundo antigo compatível e convergente com o cristianismo. ${ }^{6}$ Isso é visível, quer na leitura do martírio à luz da moral estóica e do

${ }^{6}$ Sobre esta matéria veja-se Stö̈cisme et christianisme à la Renaissance, Cahiers V.L. Saulnier, 23 (2006). 
perfil do sábio estóico, quer na progressiva afirmação de uma consciência universal do homem, embora a praxis no terreno das Missões nos revele muitas vezes entendimentos diferentes dessa 'universalidade'. Um exemplo é a contestação que em parte sofreram as medidas pastorais de D. Luís Cerqueira, bispo do Japão (1552-1614), nomeadamente as medidas relativas à formação $\mathrm{e}$ ordenação de clero nativo, bem como à criação de um calendário litúrgico próprio (Miranda Urbano, 2004: 407). ${ }^{\text {? }}$

Entretanto, na Europa, os mártires nativos eram também celebrados e propostos como modelo de santidade. A epopeia novilatina Paciecidos (Coimbra, 1640), da autoria do jesuíta Bartolomeu Pereira, destinada a celebrar o martírio de nove companheiros jesuítas em Nagasaki no ano de 1626, é um claro exemplo da consciência universal da Companhia de Jesus. Tendo como pano de fundo a aç̧ão missionária da Companhia no Japão, o poema parte da vida, missão e martírio do provincial do Japão, o P. Francisco Pacheco e único português do grupo dos nove companheiros martirizados. Eram os restantes dois europeus, (os P.e Baptista Zola e Baltasar de Torres, respectivamente italiano e espanhol), cinco japoneses, (os irmãos Gaspar Sandamatçu, Pedro Rinxei, Paulo Xinzuque, João Quinzaco e Miguel Tozo) e um coreano (Vicente Caún).

Além de celebrar o martírio destes heróis principais, o autor do poema compõe e estrutura a narrativa de modo a evocar outros mártires. Um recurso literário a que deita mão é o motivo épico da entrega do escudo ao herói (como o de Aquiles ou de Eneias), decorado, neste caso, com a representação dos combates futuros dos mártires da Companhia, cruzando-o, assim, com o motivo da visão dos heróis futuros (como a que Anquises proporciona a Eneias na descida aos Infernos). Neste escudo, os companheiros contemplam o theatrum do suplício dos mártires mas também, em alguns casos, a glória que dos 'soldados de Cristo' se estende às suas pátrias, neste caso, várias cidades portuguesas, algumas do Japão e a Ilha da Sicília (Paciecidos, XI, 258-444). Uma outra revelação é a da Bem-Aventurança, uma visão dos mártires da Companhia já na Glória, que virão em auxílio de Pacheco e dos companheiros (Paciecidos, X, 68-116). Na enumeração destes heróis, o poeta concede referências particulares a vários mártires europeus e japoneses. ${ }^{8}$

${ }^{7}$ Precioso documento vivo desta problemática é a Apologia do Japão do Padre Valentim de Carvalho, recentemente reeditada pelo Centro Cultural e Científico de Macau, com introdução e transcrição de José Eduardo Franco (Lisboa, 2007).

${ }^{8}$ Nestes versos são recordados os nomes dos Padres Carlos Spínola, Paulo Navarro, Jerónimo de Angelis e Camilo Constâncio, italianos, Sebastião Quimura, os irmãos Gonçalo Fusai, Miguel Sato, Tomás Acafuxi, António Quiuni, Agostinho Ota, Tiago Quisai e Tiago 
Outra digressão descritiva a que o poeta deita mão para elogiar os mártires locais é a de umas tabuinhas figurativas que Francisco Pacheco traria consigo, com a representação de mártires japoneses, e que apresenta aos guardas do cárcere (Paciecidos, V, 364-422). A seguir à contemplação destas imagens segue-se no poema a conversão do jovem Narciso, o que não pode deixar de ser lido como uma afirmação do poder do ícone, da sua virtude catequética e evangelizadora, por oposição à atitude iconoclasta. É de notar ainda que Francisco Pacheco apresenta aos guardas do cárcere as tabuinhas figurativas numa estratégia argumentativa de conversão, e que o poeta está ciente de que, para esses destinatários, terá maior peso o sacrificio daqueles que lhe são mais próximos, os que pertencem à mesma pátria, aqueles em que corre o mesmo sangue.

'Demovam-vos, pois, estas imagens, a visão do vosso próprio sangue vos comova; que convertam os vossos corações de pedra outras mil falanges de japoneses, homens, mulheres, crianças e velhos já sem força: quantos sofrendo o exilio cruel suportaram, pelo poder de Cristo, a prisão, as correntes, os açoites, o aguilhão, o fogo e a cruz' (Paciecidos, V, 417-422).

Paradoxalmente, a Europa dos alvores da modernidade que viveu as dificeis e tantas vezes sangrentas divisões confessionais é, simultaneamente, a Europa que vê reafirmar-se uma crescente consciência universal do homem e do mundo, alargada em parte pelos espantosos resultados da primeira globalização à escala planetária, desencadeada pelos chamados 'Descobrimentos' levados a cabo pelos reinos ibéricos. A natureza missionária do cristianismo que, sobretudo a partir do séc. XVI vê extraordinariamente alargado o seu campo de acção, contribuiu amplamente para a consolidação de uma consciência europeia universalizante. Espalhados pelos quatro cantos do mundo, os missionários europeus não estão simplesmente ao serviço dos seus reinos, mas de uma missão que têm como universal. Se atentarmos na que foi a maior ordem missionária de então, a Companhia de Jesus, verificamos que, ao serviço da Província portuguesa nas missões quer do Brasil, quer da Índia, da China e do Japão, estão jesuítas portugueses, castelhanos, franceses, italianos, flamengos, coreanos, chineses, e japoneses.

Esta consciência universalizante, porém, não a devemos confundir com o 'novo' conceito de eurocentrismo hoje tão castigado, a que, em certos meios, é politicamente correcto apontar o dedo acusador, esquecendo-nos talvez que

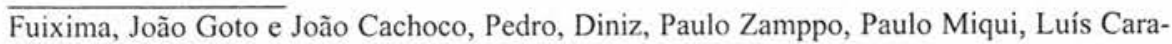
vata e Simão Hempo, japoneses e os Padres João Baptista Machado, Miguel e Diogo Carvatho e o irmão Ambrósio Fernando, portugueses. 
esse dedo acusador enferma do mesmo vício, que diríamos "egocêntrico", de autoproclamação, isto é, de uma época vivida como metro de justiça, apta, só ela, e sempre pronta, a julgar as que a precederam.

Esta consciência universalizante está enraizada no pensar universal que os humanistas da Europa moderna herdaram da cultura grega, da tradição romana e da teologia patrística, e que no contexto dos séc. XV e XVI encontrou um vasto campo de realização para se enraizar e alargar as fronteiras do universal, sem omissão do local. Julgamos, de resto, que faz parte da própria consciência europeia esta tensão constante entre um sentimento de pertença $\mathrm{e}$ de atracção à terra-mãe, gerador de identidade, e um sentimento de cidadania universal.

Nos alvores da modernidade, regressando às fontes, a Europa manifestava então, na própria paisagem ética e estética, aquela sua unidade cultural de fundo que as cisões religiosas das Reformas e a fragmentação política causada pelas emergências nacionalistas nunca lograriam de todo desmantelar, e que apontaria sempre para uma consciência do universal.

\section{BIBLIOGRAFIA}

BASLEZ, Marie-Françoise, Les persécutions dans l'antiquité. Victimes, héros, martyres, Fayard, 2007.

COSTA, J. P. Oliveira, "Bishop D. Luis Cerqueira (1552-1614) and the faith of the japanese christians", St. Francis Xavier, an apostle of the East, ed. The executive committee 450th anniversary of the arrival of St. Francis Xavier in Japan, Sophia University Press, 2000, vol. 2, 105-121.

ELLIOT, Alison Goddard, Roads to Paradise, Brown University Press, Hanover, London, 1987.

FREDOUILLE, Jean-Claude, "Le héros et le Saint", Du Héros païen au saint chrétien. Actes...Collection des Études Augustiniennes, 1997, 11-25.

GIRARD, René, Celui par qui le scandale arrive, Hachette, Desclée de Brouwer, 2001.

GREGORY, Brad S., Salvation at stake. Christian Martyrdom in Early Modern Europe, Harvard University Press, Cambridge, Massachusetts and London, England 1999.

LESTRINGANT, Frank, Lumière des Martyres, Honoré Champiom, Paris, 2004.

LOPES S.I., José Manuel Martins, Santo Inácio de Loiola, um educador do desejo, Braga, AO, 2003.

MIRANDA URBANO, Santos e Heróis. A épica hagiográfica novilatina e o poema Paciecidos (1640) de Bartolomeu Pereira SJ, Dissertação de doutoramento apresentada à Universidade de Coimbra, texto policopiado, Coimbra, 2004. 
idem "Para que servem os heróis? Ideal de missão e martírio na pedagogia espiritual jesuitica (séc. XVI-XVII)", Repensar a escola hoje. O contributo dos jesuitas, Universidade Católica Portuguesa, Faculdade de Filosofia, Braga, 2007, pp. 505-518.

idem, "'Mori lucrum' O ideal de missão e martírio e as missões jesuítas do extremo Oriente nos séc. XVI e XVII", Biblos n.s. 2 (2004) 131-153.

MIRANDA, J. Carlos, Tertuliano. Apologético, edição bilingue com tradução, Introdução e comentários, Alcalá, 2002

PEREIRA, Bartolomeu, Paciecidos: libri duodecim: decantatur clarissimus P. Franciscus Paciecus Lusitanus, Pontlimiensis, è Societate Iesu, Japponiae Provincialis eiusdem Ecclesiae Gubernator, ibique uiuus pro Christi fide lento concrematus anno 1626. Conimbricae, Expensis Emmanuelis de Carvalho 1640.

Stoïcisme et christianisme à la Renaissance, Cahiers V.L. Saulnier, 23 (2006).

SOARES, Nair de Nazaré C., "Humanismo e História: ars scribendi e valor do paradigma" Máthesis, 1 (1992) 154-169. 